\title{
Discovering HDAC class II selective inhibitors by multidisciplinary approach
}

\author{
S Lorenzi ${ }^{1 *}$, A Beccari ${ }^{1}$, D Carettoni ${ }^{2}$, M Rubino ${ }^{2}$, V Nardese $^{2}$ \\ From 6th German Conference on Chemoinformatics, GCC 2010 \\ Goslar, Germany. 7-9 November 2010
}

A number of cellular processes, as cell proliferation, apoptosis and cytoskeleton assembly [1], are regulated by enzymes belonging to the family of histone deacetylases (HDACs). Extended or local changes in chromatin structure are driven by an interplay between histone acetyltransferases (HATs) and HDACs, and both of enzymes are involved in post-translational modifications of histones involving the control of the genes expression [2]. One of the most studied post-modification is the acetylation of the lysine residues in the $\mathrm{N}$-terms of the histone cores mediated by the HDACs enzymes, which contains four distinct subgroups: CLASS I (HDACs 1, 2, 3 and 8), CLASS II (HDACs 4, 5, 6 and 7), CLASS III (SIRTUINS) and CLASS IV (HDAC11).

The enzyme under study was the HDAC7 and due to the absence of specific inhibitors of this enzyme we adopt both ligand-based and structure-based approaches to filter from a 7 million commercial compounds database, an ensemble of molecules to test versus HDAC7.

The starting point of our approach was to collect all Metal-Binding heads (MTH) and all kind of Linker between the MTH and the Capping Groups of all available compounds binding all HDACs, and generate all possible combinations among all three moieties. All compounds of this virtual database have been submitted to a conformational search in which a maximum of 255 conformers have been stored per molecules. This last 3D virtual database has been filtered by a pharmacophore built on the tridimensional structure of the HDAC7 in complex with TSA (PDB ID: 3C10).

The molecules able to satisfy the pharmacophore have been submitted to a docking phase to filter molecules with a high propensity to interact with HDAC7 enzyme. A panel of 960 compounds have been purchased and

\footnotetext{
*Correspondence: simone.lorenzi@dompe.it

'DrugDiscovery Dept., Dompé spa, L'Aquila,I-67100, Italy

Full list of author information is available at the end of the article
}

tested on HDAC7 and the most interesting have been characterized against other HDACs.

\section{Author details \\ 'DrugDiscovery Dept., Dompé spa, L'Aquila,I-67100, Italy. ${ }^{2}$ AXXAM spa, Milano, I-20132, Italy.}

Published: 19 April 2011

\section{References}

1. de Ruijter AJ, van Gennip AH, Caron HN, Kemp S, van Kuilenburg AB: Histone deacetylases (HDACs): characterization of the classical HDAC family. Biochem I 2003, 370:737-749.

2. Strahl $B D$, Allis $C D$ : The language of covalent histone modifications. Nature 2000, 403:41-45.

\section{doi:10.1186/1758-2946-3-S1-P2}

Cite this article as: Lorenzi et al: Discovering HDAC class II selective inhibitors by multidisciplinary approach. Journal of Cheminformatics 2011 3(Suppl 1):P2.

\section{Publish with ChemistryCentral and every scientist can read your work free of charge \\ "Open access provides opportunities to our colleagues in other parts of the globe, by allowing anyone to view the content free of charge." \\ W. Jeffery Hurst, The Hershey Company. \\ - available free of charge to the entire scientific community \\ - peer reviewed and published immediately upon acceptance \\ - cited in PubMed and archived on PubMed Central \\ - yours - you keep the copyright \\ Submit your manuscript here: \\ http://www.chemistrycentral.com/manuscript/

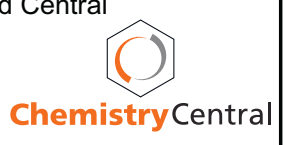

